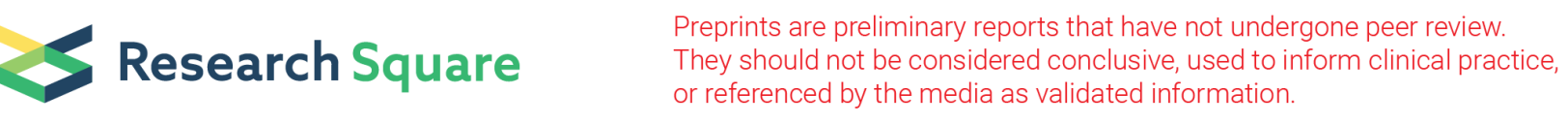

\title{
Bovine Coronavirus Infections in Turkey: Molecular Analysis of the Full-Length Spike Gene Sequences of Viruses From Digestive and Respiratory Infections
}

\section{Secil Sevinc Temizkan ( $\sim$ sevinc@ankara.edu.tr)}

Ankara Universitesi Saglik Bilimleri Enstitusu https://orcid.org/0000-0002-2427-3877

\section{Feray Alkan}

Ankara Universitesi Saglik Bilimleri Enstitusu

\section{Original Article}

Keywords: Coronavirus, Bovine coronavirus, S gene, Sequencing

Posted Date: February 17th, 2021

DOI: https://doi.org/10.21203/rs.3.rs-204481/v1

License: (c) (i) This work is licensed under a Creative Commons Attribution 4.0 International License. Read Full License 


\section{Abstract}

BCoV can be spread by animal activity. Despite the widespread cattle farming in the region, limited studies exist in Turkey about BCoV. The aim of this study was to reveal the latest aspects in Turkey about BCoV and evaluate the data. This is the first study reporting the full-length sequences of S genes of BCoV in Turkey.

In this study samples were collected from 119 cattle, presenting clinical signs of respiratory $(n=78)$ or digestive tract infection $(n=41)$ in distinctive farms located in widely different provinces of Turkey. Samples were screened for bovine coronavirus (BCoV) by a RT-nested PCR targeting the $\mathrm{N}$ gene. BCoV was found positive in 35 samples ( 9 faeces and 26 nasal discharge) and RT-PCR analysis of the $S$ gene was performed. The partial/full-length $S$ gene sequences were able to be obtained from 11 samples (8 faeces and 3 nasal discharge). Phylogenetic tree of the $S$ gene sequences was analyzed for the genetic relationships among BCoVs from Turkey and other countries. Results showed that many different amino acid changes exist in local strains and these changes were persistent in faeces and nasal discharge origin. Likewise, some nucleotide and amino acid changes were compatible with previous studies which have critical importance for tropism. These results could represent a novelty in the current literature adding new data on BCoV from Turkey and these data could have potentially positive effects on the vaccination approach and control strategies due to lack of information.

\section{Introduction}

The coronaviruses cause infections in many species, including humans. In the last decade, they have gained importance among zoonotic viruses after SARS-coronavirus (SARS-CoV) and MERS-CoV infections and recently COVID-19 pandemic caused by a novel coronavirus named SARS-coronavirus-2 (SARS-CoV-2) [1-3]. In animals, coronavirus is etiologically associated with enteric and respiratory disease across a wide range of mammalian and avian species. Bovine coronavirus (BCoV) is mainly recognized as a cause of severe neonatal calf diarrhea. It has also emerged as the reasons that the winter dysentery in adult cattle and the respiratory tract illnesses in calves and adult cattle, leads to economic losses to the livestock industry [4-6].

BCoV belongs to the species Betacoronavirus 1, which was recently assigned by the International Committee on Taxonomy of Viruses (ICTV) to the order Nidovirales, suborder Cornidovirineae, family Coronaviridae, subfamily Orthocoronavirinae, genus Betacoronavirus, and subgenus Embecovirus [7]. The genome is 31,028 base length, contains linear and single-stranded RNA [8]. BCoV genome consists of five structural genes: the phosphorylated nucleocapsid (N), the integral membrane (M), and small membrane (E), the hemagglutinin/esterase (HE), spike (S) genes [9]. S genes that synthesized the S protein has an important function in viral infectivity. The S glycoprotein is cleaved into S1 (N terminus) and S2 (C terminus) subunits by an intracellular protease [10]. The S glycoprotein has two main biological functions: the attachment to target cells and the fusion of viral and cellular membranes [11-13]. S1 is responsible for attaching the large receptor binding domain of $S$ protein to cell receptors and induces neutralizing antibodies and hemagglutination activity. In the meantime, the S2 protein mediates the fusion of viral and cellular membranes by forming a "spear-like" stem. Besides, the S2 subunit is highly conserved and the S1 subunit is more variable among BCoVs [6, 13-15]. It is known that the mutational changes in amino acid composition in cleavage sites may have a significant effect on altered tissue and cell tropism and pathogenicity.

Although there have been reports about the presence of BCoV in Turkey until 2011, the first detailed molecular study was conducted by Alkan et al. [16]. The partial sequence of the $S$ gene of 2 faeces samples was obtained in their study. Seroprevalence studies have been continued for many years, but detailed molecular studies have not been conducted.

The first aim of this research was to unveiled the full-length $S$ gene of Bovine coronaviruses in Turkey. Relatedly that, the research could lead to novelty in the current literature adding new data on BCoV from Turkey and these data could have 
potentially positive effects on the vaccination approach and control strategies. Another aim of the study was to present the possible interaction of digestive and respiratory agents of the BCoVs.

\section{Materials And Methods}

\section{Sampling}

A total of 119 samples from cattle suspected of BCoV infection breed in the different farms and widely distributed provinces of Turkey between 2001 and 2019 were used (Fig. 1). Faecal samples $(n=41)$ were obtained from animals ages 4 days to 15 months and nasal discharge $(n=78)$ was obtained from animals aged 7 days to $5 \geq$ years. Details of sample information are summarized in Table 1.

Samples were diluted 1:10 ( $\mathrm{v} / \mathrm{v}$ and $\mathrm{w} / \mathrm{v}$ for nasal discharge and faeces, respectively) in phosphate-buffered saline solution and centrifuged at $3,000 \times$ rpm for 20 minutes at $4{ }^{\circ} \mathrm{C}$. Then, supernatants were collected and stored at $-80^{\circ} \mathrm{C}$.

\section{RNA Extraction and Reverse Transcription}

Viral RNA was extracted using TRIzol ® LS Reagent (Thermo Fisher Scientific), following the manufacturer's instructions. Reverse transcription (RT) was carried out using Geneall ${ }^{\circledR}$ HyperScript ${ }^{\mathrm{TM}}$ First-Strand Synthesis Kit according to the manufacturer's protocol. All RNAs and cDNAs were stored at $-80^{\circ} \mathrm{C}$.

\section{Polymerase Chain Reaction For N And S Gene Regions of Local BCoVs}

To investigate the presence of $\mathrm{BCoV}$, a nested PCR assay targeting the $\mathrm{N}$ gene region was carried out using the primers and methods previously described [17]. All PCR reactions were performed using Thermo Scientific DreamTaq DNA Polymerase with the use of Biometra (Germany) Thermal Cycler.

Briefly, for the first round of nested PCR for $\mathrm{N}$ gene amplification, $2.5 \mu \mathrm{l}$ cDNA was added to the mixture of $2.5 \mu \mathrm{l}$ of $10 \mathrm{X}$ DreamTaq buffer, $0.5 \mu \mathrm{l}$ of $10 \mathrm{mM}$ dNTP mix, $1 \mu \mathrm{l}$ of $10 \mu \mathrm{M}$ primers (BCoV N-F/BCoV N-R), $0.25 \mu$ l of DreamTaq DNA polymerase $(5 \mathrm{U} / \mu \mathrm{l})$ and $17.25 \mu \mathrm{l}$ of nuclease-free water per sample. The PCR was performed according to the following protocol: an initial step of 3 minutes at $95^{\circ} \mathrm{C}$, followed by 35 cycles of $95^{\circ} \mathrm{C}$ for 30 seconds, $50{ }^{\circ} \mathrm{C}$ for 30 seconds, and $72{ }^{\circ} \mathrm{C}$ for 1 minute, and a final extension at $72{ }^{\circ} \mathrm{C}$ for 10 minutes. The second round was conducted with the same master

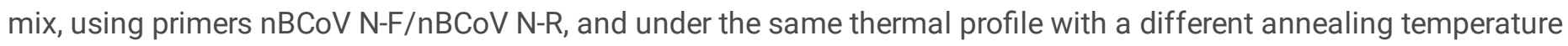
$\left(58^{\circ} \mathrm{C}\right)$. Thereafter, the samples which show positive results for the $\mathrm{N}$ gene were used for the $\mathrm{S}$ gene amplification $(4,112$ bp) with various primer pairs as previously reported $[1,6,18]$ (Supplement 1$)$.

For the PCRs for S gene region amplification, with separate master mixes each consisting $2.5 \mu \mathrm{l}$ cDNA was added to the mixture of 10X Dream DreamTaq buffer $2.5 \mu \mathrm{l}, 10 \mathrm{mM}$ dNTP mix $0.5 \mu \mathrm{l}, 1 \mu \mathrm{l}$ of $10 \mu \mathrm{M}$ primers (Supplement 1 ), $0.25 \mu \mathrm{l}$ of Dream Taq DNA polymerase $(5 \mathrm{U} / \mu \mathrm{l})$ and $17.25 \mu \mathrm{l}$ of nuclease-free water per sample. The PCR was performed according to the following protocol: an initial step of 3 minutes at $95^{\circ} \mathrm{C}$, followed by 35 cycles of $95^{\circ} \mathrm{C}$ for 30 seconds, $51-58{ }^{\circ} \mathrm{C}$ for 30 seconds for the different reactions (Supplement 1), and $72{ }^{\circ} \mathrm{C}$ for 1 minute, and a final extension at $72{ }^{\circ} \mathrm{C}$ for 10 minutes. Each amplicon was analyzed on a 1\% agarose gel stained with Safeview ${ }^{\mathrm{TM}}$ Classic (NextGen Life Sciences Private Limited) and using $1 \mu \mathrm{l}$ of $100 \mathrm{bp}$ marker (Fermentas, Lithuania) to determine the product size.

\section{Sequence and Phylogenetic Analysis}

Sequence analysis of PCR products was performed by a commercial company (BM Labosis, BM Lab. Schist. Ltd. Sti. Ankara, Turkey). Obtained sequences were identified using the BLAST (Basic Local Alignment Search Tool) provided by NCBI (National Center for Biotechnology Information) web page. Sequences were aligned using Aliview software [19], utilizing the references viral sequences extort from the GenBank [9, 20]. Following alignment, amino acid sequences and 
sequence variation tables were braced MEGA X and Aliview software's based on nucleotide sequences. The sequences were submitted to the GenBank database under accession numbers MK787427-MK787439 and MK989614-MK989619 for the $\mathrm{N}$ gene and $\mathrm{S}$ gene sequences were shown in Table 2.

Nucleotide homology analyzes for the similarity comparisons equations were generated using the SIAS [21] web tool.

Phylogenetic relationships of S gene partial/full-length nucleotide and amino acid sequences among a number of other BCoV strains in the world (Fig. 2) (Supplement 2) analyzed using the neighbor-joining methodology with MEGA X software. Neighbour-joining trees were computed with p-distance parameters and confidence levels were estimated by 1000 bootstrap replicates.

\section{Results}

\section{Detection of BCoV}

35 samples out of 119, were found positive for the $\mathrm{N}$ gene fragments (407 bp). Gel electrophoresis results of some of the amplicons were presented in Supplement 3. The positivity rates were $21.9 \%(9 / 41)$ and $33.3 \%(26 / 78)$ for the faecal and nasal discharge samples, respectively.

\section{Molecular Characterization of the S Gene of BCoVs and Phylogenetic Analysis}

S gene PCR results were evaluated for 35 the BCoV positive samples, however not all samples were found to be amplicon positive. Nonetheless, as presented in Table 2, the full-length $S$ gene was obtained from 5 samples ( 3 faecal and 2 nasal discharge). Further, the partial S gene was obtained from 6 samples (4 faecal and 2 nasal discharge). As it is expected, the amplicons from various regions of the $S$ gene were not always in the same region. Solely, 488 bp S1 region amplified by S1 primers (Supplement 1) that plays a critical role in tropism and antigenicity was amplicon positive in total 11 samples ( 5 from full-length) and that region was used for the nucleotide and amino acid comparisons and phylogenetic analyses. Gel electrophoresis results of some of the amplicons were presented in Supplement 4.

The alignment of the deduced amino acid sequences from the mentioned gene fragment sequences of $11 \mathrm{BCoVs}$ S1 region amplified by $\mathrm{S} 1$ primers samples (488 bp) with that of the Mebus strain demonstrated some changes. Notably, all samples with one exception (BCoV / Turkey / 1N / 2019, Acc. no: MK989625) has great numbers of amino acid differences (Table 3). Among mutations, most were synonymous mutations with the mutation detected in other local sequences (GQ259978 and GQ259979) previously reported [16]. No frameshift mutations, deletions, insertions or recombinations have been found in that study. In addition, no relationship was found between the nucleotide or amino acid changes and the type of material from which the virus originated (Table 3).

Comparison of the nucleotide and amino acid similarities of faeces $(n=3)$ samples between each other were $97.6-99.0 \%$ and $96.9-98.2 \%$ and nasal discharge $(n=2)$ samples between each other were $97.8 \%$ and $97.7 \%$, respectively. The fulllength $S$ genes results $(n=5)$ showed that; nucleotide similarities was $97.4-99.0 \%$ and amino acid similarities was $96.9-$ $98.2 \%$ between these sequences. Comparison of the nucleotide similarities of full-length $S$ genes sequences $(n=5)$ with Mebus strain from faeces and LSU strain from nasal discharge, were 96.9-97.5\% and 97.3-97.9\%, respectively. Identity rates are also calculated by SIAS for the partial sequences $488(\mathrm{bp})$ from local strains. The partial S1 gene sequences $(\mathrm{n}=$ 11) showed $90.92-100 \%$ nucleotide identity and $87.4-100 \%$ amino acid identity to each other. They have $94.78-99.11 \%$ and $96.23-97.72 \%$ nucleotide identity to Mebus and LSU strains, respectively. According to the similarity analysis of partial sequences (488 bp) made considering the sample types, the nucleotide and amino acid similarities are as follows: 90.92-100\% nucleotide and $90.5-100 \%$ amino acid identities from the faeces $(n=7)$ samples between each other and were $95.13-98.75 \%$ nucleotide and $90-96.8 \%$ amino acid identities from nasal discharge $(n=4)$ samples between each other. 
The phylogenetic tree is constructed from the local full-length $(4,112) \mathrm{S}$ gene samples with other randomly selected BCoV S gene sequences around the world (Supplement 2), shown in Fig. 2-A and Fig. 2-C. The phylogenetic tree constructed from the local partially sequenced S1 region amplified by S1 primers (488 bp) with other local sequences [16] and more randomly selected BCoV S gene partial S1 sequences around the world (Supplement 2), shown in Fig. 2-B and Fig. 2-D. Fig. A and B were constructed with amino acid sequences, while fig. $C$ and $D$ were created via nucleotide sequences.

\section{Discussion}

In this study; BCoV suspected faeces and nasal discharge samples were collected from all around Turkey $(n=119)$ and positive samples $(n=35)$ were scanned with molecular analyzes for the $S$ gene region. $21.9 \%(9 / 41)$ of the faeces and $33.3 \%$ (26/78) of the nasal discharge samples were found positive. In previous studies conducted in Turkey, BCoV was reported in significant numbers in cases of calf diarrhea, alongside with many other enteropathogens [22-28]. Besides, various faeces based serological studies shown the prevalence of the BCoV in cattle in Turkey [16, 26, 28-32]. Apart, two studies were present the prevalence of the nasal discharge associated BCoV in Turkey $[29,33]$. The prevalence results of this study were found to be consistent with other studies conducted in Turkey. Also, the prevalence of the BCoV in divergent regions of the world is considerably similar with this study and Turkey [5, 34-40].

Numerous studies based on partial or full-length $S$ gene sequences have been conducted to determine the biological, antigenic and genetic characteristics of BCoV strains derived from respiratory system infection and enteric infections [1, 18, 41-42]. Previous studies have been determined that the virus affecting both systems is identical and has dual tropism $[5,17-18]$. Examination of the amino acid similarity results of the BCoV S gene region partial / full-length sequences in this study shown that; high similarity rates were found between these studies results between each other (87.4-100\%) and with reference strains (94.78-99.11\%). Withal, the phylogenetic trees (Fig. 2) constructed using BCoV S gene region partial / full-length sequences in the present study shown that; respiratory or digestive system origin does not make a significant difference in phylogenetic tree placement and amino acid similarity rates were found, which is akin to the other studies worldwide $[9,20,34-35,40-41]$.

The S1 subunit of the S protein is responsible for the binding of the virus to host cell receptors, stimulation of neutralizing antibody synthesis and hemagglutinin activity $[12,15,43]$. Changes in this subunit could be conspicuously effective in terms of antigenicity and pathogenicity [44]. In the present study, BCoV S gene region partial / full-length nucleotide and amino acid variations (Table 3 ) and phylogenetic trees shown that the $\mathrm{S} 1$ subunit is more susceptible to genetic variability than the S2 subunit, as previously reported in Turkey [16] and in the world [18, 45-46].

Recognizedly, mutations ensure significant contributions to the survival of infectious agents in nature. Further, while many mutations would not cause any notable differentiations in the structure of the virus, some could even possibly to lead cross-species transmission or increased contagiousness. One of the most recent and striking examples is that the SARSCoV-2 S1 region $614(D \rightarrow G)$ mutation cause to increase in its infectivity of the virus [47]. Another, six amino acid deletion (526-531) of the Brazilian BCoV strains have the same amino acid sequence as Human coronavirus (HCoV) OC43 [1]. In this study, multiple changes were observed in the local BCoV S gene amino acid sequences. Moreover, as it is seen on the reference strain Mebus based amino acid variation table, this studies sequences and two previously reported local viruses (GQ259978 and GQ259979) contains some persistent changes on full-length S gene. Additionally, similar persistent changes also apprehensible for different countries (Table 3). Exceptionally, in one sample (BCoV/Turkey/IN/2019 with acc. Number MK989625) these changes were not seen, and it was seen that it has the same sequences as Mebus. Hence, the sample which has the closest position to Mebus in the phylogenetic tree was this sample. The possible reason could be considered to be the vaccination shortly before the sampling but no evaluation could not be doable because no information was obtained on this matter. 
Vaccination has a crucial role to protection from infections. Among the factors affecting achieved vaccination, the level of antigenic affinity between the vaccine strain and local strains is exclusively important. The increase in antigenic differences may occur due to serotype differences and variations resulting from spontaneous mutations. Previous studies reported that one amino acid differentiation of $B C o V 528(A \rightarrow V)$ may cause resistance to neutralization [12]. In the present study, no $528(A \rightarrow V)$ mutations were found in local BCoVs. Consequently; based on these study's data, present vaccines are protective at a certain level, however, further studies should be conducted on whether amino acid changes in the antigenic domains of local viruses would lead to resistance occurrence or not.

\section{Conclusions}

As a result, the full-length BCoV S gene is presented for the first time in Turkey. In evaluating the sequence results, it has been demonstrated once again that the strains of BCoVs affecting both the digestive and respiratory systems are the same. Sequence differences of the local strains and the strains in the previous works of literature were found greatly similar. Moreover, sequence differences of the local strains and the strains used for vaccination were found insignificant. No sample has shown $528(A \rightarrow V)$ mutation which is important for the neutralization and vaccination. Also, no frameshift mutations, deletions, insertions or recombinations have been found. Consequently; this study has shown, BCoV still continues to exist widely in Turkey and present vaccines are protective at a certain level.

\section{Declarations}

\section{Funding}

This project was funded by the Ankara University Scientific Research Projects Coordination Unit (Project no.18L0239002).

\section{Conflict of Interest}

All Authors declare that there are no financial or other relationships that might lead to a conflict of interest. All authors have seen and approved the manuscript and have contributed significantly to the work.

\section{Ethics Approval}

The study accepted of ethical commitee of Ankara University with the document number 2017-15-127.

\section{Acknowledgments}

This manuscript represents part of a thesis submitted by SST to the Department of Virology, Graduate School of Health Sciences, Ankara University, in fulfillment of the requirements for a Ph.D. degree.

\section{References}

1. Brandao PE, Gregori F, Richtzenhain LJ, Rosales CAR, Villarreal LYB, Jerez JA (2006) Molecular analysis of Brazilian strains of bovine coronavirus (BCoV) reveals a deletion within the hypervariable region of the S1 subunit of the spike glycoprotein also found in human coronavirus OC43. Arch Virol 151: 1735-1748. https://doi.org/10.1007/s00705006-0752-9

2. Huang C, Wang Y, Li X, Ren L, Zhao J, Hu Y, Zhang L, Fan G, Xu J, Gu X, Cheng Z, Yu T, Xia J, Wei Y, Wu W, Xie X, Yin W, Li H, Liu M, Xiao Y, Gao H, Guo L, Xie J, Wang G, Jiang R, Gao Z, Jin Q, Wang J, Cao B (2020) Clinical features of patients infected with 2019 novel coronavirus in Wuhan, China. The lancet 395(10223), 497-506.

https://doi.org/10.1016/S0140-6736(20)30183-5 
3. Song Z, Yanfeng X, Bao L, Zhang L, Yu P, Qu Y, Zhu H, Zhao W, Han Y, Qin C (2019) From SARS to MERS, thrusting coronaviruses into the spotlight. Viruses 11(1). https://doi.org/10.3390/v11010059

4. Anthony SJ, Johnson CK, Greig DJ, Kramer S, Che X, Wells H, Hicks AL, Joly DO, Wolfe ND, Daszak P, Karesh W, Lipkin WI, Morse SS, Predict Consortium, Mazet JAK, Golstein T (2017) Global patterns in coronavirus diversity. Virus Evol 3(1): 1-15. https://doi.org/10.1093/ve/vex012

5. Beuttemmuller EA, Alfieri AF, Headley SA, Alfieri AA (2017) Brazilian strain of bovine respiratory coronavirus is derived from dual enteric and respiratory tropizm. Genet Mol Res 16(2): 1-7. https://doi.org/10.4238/gmr16029580

6. Martinez N, Brandao PE, Souza SP, Barrera M, Santana N, Arce HD, Perez LJ (2012) Molecular and phylogenetic analysis of bovine coronavirus based on the spike glycoprotein gene. Infect Genet Evol 12: 1870-1878. https://doi.org/10.1016/j.meegid.2012.05.007

7. ICTV (2016). International Committee on Taxonomy of Viruses. https://talk.ictvonline.org/taxonomy/. Date of Access: 05/06/2018.

8. Maclachlan NJ, Dubovi EJ (2011) Fenner's Veterinary Virology 4th Edition. Academic Press Elsevier. USA

9. Chouljenko VN, Kousoulas KG, Lin X, Storz J (1998) Nucleotide and predicted amino acid sequences of all genes encoded by the $3^{\prime}$ genomic portion $(9.5 \mathrm{~kb})$ of respiratory bovine coronaviruses and comparisons among respiratory and enteric coronaviruses. Virus Genes 17(1): 33-42. https://doi.org/10.1023/a:1008048916808

10. Saif LJ (2010) Bovine respiratory coronavirus. Vet Clin North Am Food Anim Pract 26(2): 349-364. https://doi.org/10.1016/j.cvfa.2010.04.005.

11. Beniac DR, Andonov A, Grudeski E, Booth TF (2006) Architecture of the SARS coronavirus prefusion spike. Nat. Struct Mol Biol 13(8): 751-752. https://doi.org/10.1038/nsmb1123

12. Yoo D, Deregt $D$ (2001) A single amino acid change within antigenic domain II of the spike protein of bovine coronavirus confers resistance to virus neutralization. Clin Diagn Lab Immunol 8: 297-302.

https://doi.org/10.1128/CDLI.8.2.297-302.2001

13. Yoo DW, Parker MD, Babiuk LA (1991) The S2 subunit of the spike glycoprotein of bovine coronavirus mediates membrane fusion in insect cells. Virology 180(1): 395-399. https://doi.org/10.1016/0042-6822(91)90045-D

14. Fehr AR, Perlman S (2015) Coronaviruses: An Overview of Their Replication and Pathogenesis. Methods Mol Biol 1282: 1-23. https://doi.org/10.1007/978-1-4939-2438-7_1

15. Kubo H, Yamada YK, Taguchi F (1994) Localization of neutralizing epitopes and the receptor-binding site within the amino-terminal 330 amino acids of the murine coronavirus spike protein. J Virol 68(9): 5403-5410.

https://doi.org/10.1128/JVI.68.9.5403-5410.1994

16. Alkan F, Ozkul A, Bilge-Dagalp S, Karaoglu T, Oguzoglu TC, Caliskan E, Burgu I (2011) The Detection and Genetic Characterization Based on the S1 Gene Region of BCoVs from Respiratory and Enteric Infections in Turkey.

Transbound Emerg Dis 58(2): 179-185. https://doi.org/10.1111/j.1865-1682.2010.01194.x

17. Cho KO, Hasoksuz M, Nielsen PR, Chang KO, Lathrop S, Saif LJ (2001) Cross-protection studies between respiratory and calf diarrhea and winter dysentery coronavirus strains in calves and RT-PCR and nested PCR for their detection. Arch Virol 146: 2401-2419. https://doi.org/10.1007/s007050170011

18. Hasoksuz M, Sreevatsan S, Cho KO, Hoet AE, Saif LJ (2002) Molecular analysis of the S1 subunit of the spike glycoprotein of respiratory and enteric bovine coronavirus isolates.Virus Res 84: 101-109. https://doi.org/10.1016/S0168-1702(02)00004-7

19. Larsson A (2014) Aliview: A fast and lightweight alignment viewer and editor for large datasets. Bioinformatics 30 : 3276-3278. https://doi.org/10.1093/bioinformatics/btu531

20. Mebus CA, White RG, Stair EL, Rhodes MB, Twiehaus MJ (1972) Neonatal calf diarrhea: results of a field trial using a reo-like virus vaccine. Vet Med Small Anim Clin 67: 173-178. 
21. SIAS (2020). Sequence Identity And Similarity. http://imed.med.ucm.es/Tools/sias.html/. Date of Access: 06/01/2020.

22. Alkan F (1998) Buzağı ishallerinde rotavirus ve coronavirusların rolü. Ankara Univ. Vet. Fak. Derg. 45: 29-37.

23. Cabalar M, Kaya A, Arslan S (2007) Yeni doğan buzağıların ishal olgularında rotavirus ve coronavirus araştırılması. Vet Bil Derg 23(3-4): 103-106.

24. Erdogan HM, Unver A, Gunes V, Citil M (2003) Frequency of rotavirus and coronavirus in neonatal calves in Kars district. Kafkas Univ Vet Fak Derg 9(1): 65-68.

25. Gumusova SO, Yazıcı Z, Albayrak H, Meral Y (2007) Rotavirus and coronavirus prevalence in healthy calves and calves with diarrhea. Medycnya Wet 63: 62-64.

26. Hasircioglu S (2005) Buzağılarda enterik BCoV enfeksiyonlarının araştırılması ve epidemiyolojide klinik olarak sağlıklı sığırların rolü. Access Address:

[http://acikerisim.selcuk.edu.tr:8080/xmlui/bitstream/handle/123456789/5050/163292.pdf? sequence=1\&isAllowed=y]. Date of Access: 31/03/2019.

27. Kozat S, Tuncay I (2018) Prevalance of Rotavirus, Coronavirus, Cryptosprodium spp., Escherichia coli K 99, and Giardia lamblia pathogens in neonatal calves with diarrheic in Siirt Region. Van Vet J 29(1): 17-22.

28. Yavru S, Yapici O, Kale M, Sahinduran S, Pehlivanoglu F, Albay MK, Avcı O (2016) Bovine coronavirus (BoCV) infection in calves with diarrhoea and their dams. Acta Sci Vet 44: 1-7.

29. Hasoksuz M, Kayar A, Dodurka T, Ilgaz A (2005) Detection Of Respiratory And Enteric Shedding Of Bovine Coronaviruses In Cattle In Northwestern Turkey. Acta Vet Hung 53: 137-146.

30. Sakli GU (2017) İshalli buzağı dışkılarında sığır coronavirusu ve sığır rotavirusunun hızı tanı kiti ve rt-pcr ile araştırılması. Access Address: [http://acikerisim.selcuk.edu.tr:8080/xmlui/bitstream/ handle/123456789/10176/462482.pdf?sequence=1\&isAllowed=y]. Date of Access: 31/03/2019.

31. Tokgoz BS, Ozdemir R, Turut N, Mirioglu M (2013) Adana Bölgesinde Görülen Neonatal Buzağı Enfeksiyonlarının Morbidite ve Mortaliteleri ve Risk Faktörlerinin Belirlenmesi. AVKAE Derg 3(1): 7-14.

32. Yildirim Y, Dagalp SB, Tan MT, Kalaycioglu AT (2008) Seroprevalence of the Rotavirus and Coronavirus infections in cattle. J Anim Vet Advances 7: 1320-1323.

33. Timurkan MO, Aydın H, Belen S (2015) Erzurum Bölgesinde Sığırlarda Respiratorik Coronavirus Enfeksiyonunun RTPCR ile Tespiti ve Moleküler Karakterizasyonu. Atatürk Üni Vet Bil Derg 10(3): 186-192.

34. Bidokhti MR, Traven M, Krishna NK, Munir M, Belak S, Alenius S, Cortey M (2013) Evolutionary dynamics of bovine coronaviruses: natural selection pattern of the spike gene implies adaptive evolution of the strains. J Gen Virol 94(9): 2036-2049.

35. Boireau P, Cruciere C, Laporte J (1990) Nucleotide sequence of the glycoprotein S gene of bovine enteric coronavirus and comparison with the S proteins of two mouse hepatitis virus strains. J Gen Virol 71(2): 487-492.

36. Decaro N, Elia G, Campolo M, Desario C, Mari V, Radogna A, Colaianni ML, Cirone F, Tempesta M, Buonavoglia C (2008a) Detection of bovine coronavirus using a TaqMan-based realtime RT-PCR assay. J Virol Methods 151: 167171.

37. Gunn L, Collins PJ, O'connell MJ, O'shea H (2015) Phylogenetic investigation of enteric bovine coronavirus in Ireland reveals partitioning between European and global strains. Ir Vet J 68(31): 1-7. https://doi.org/10.1186/s13620-0150060-3

38. Park SJ, Kim GY, Choy HE, Hong YJ, Saif LJ, Jeong JH, Park SI, Kim HH, Kim SK, Shin SS, Kang MI, Cho KO (2007) Dual enteric and respiratory tropizms of winter dysentery bovine coronavirus in calves. Arch Virol 152(10):1885-900. https://doi.org/10.1007/s00705-007-1005-2 
39. Fernandes AM, Brandao PE, Lima MS, Martins MSN, Silva TG, Pinto VSC, Paula LT, Vicente MES, Okuda LH, Pituco EM (2018) Genetic diversity of BCoV in Brazilian cattle herds. Vet Med Sci 4: 183-189. https://doi.org/10.1002/vms3.102

40. Shin J, Tark D, Le VP, Choe S, Cha RM, Park GN, Cho IS, Nga BTT, Lan NT, An DJ (2019) Genetic characterization of bovine coronavirus in Vietnam. Virus Genes 55(3):415-420. https://doi.org/10.1007/s11262-019-01647-1

41. Decaro N, Mari V, Desario C, Campolo M, Elia G, Martella V, Greco G, Cirone F, Colaianni ML, Cordioli P, Buonavoglia C (2008b) Severe outbreak of bovine coronavirus infection in dairy cattle during the warmer season. Vet Microbiol 126(1-3): 30-39. https://doi.org/10.1016/j.vetmic.2007.06.024

42. Liu L, Hagglund S, Hakhverdyan M, Alenius S, Larsen LE, Belak S (2006) Molecular Epidemiology of Bovine Coronavirus on the Basis of Comparative Analyses of the S Gene. J Clin Microbiol 44(3): 957-960. https://doi.org/10.1128/JCM.44.3.957-960.2006

43. Schultze B, Gross HJ, Brossmer R, Herrler G (1991) The spike protein of bovine coronavirus is a hemagglutinin recognizing 9-Oacetylated sialic acid as a receptor determinant. J Virol 65: 6232-6237. https://doi.org/10.1128/JVI.65.11.6232-6237.1991

44. Ballesteros ML, Sanchez CM, Enjuanes L (1997) Two amino acid changes at the N-terminus of transmissible gastroenteritis coronavirus spike protein result in the loss of enteric tropizm. Virology 227: 378-388. https://doi.org/10.1006/viro.1996.8344

45. Gallagher TM, Buchmeier MJ (2001) Coronavirus spike proteins in viral entry and pathogenesis. Virology 279: 371374. https://doi.org/10.1006/viro.2000.0757

46. Takiuchi E, Alfieri AF, Alfieri AA (2008) Molecular analysis of the bovine coronavirus S1 gene by direct sequencing of diarrheic fecal specimens. Brazilian Journal of Medical and Biological Research 41.4: 277-282. https://doi.org/10.1590/s0100-879x2008000400004

47. Zhang L, Jackson CB, Mou H, Ojha A, Rangarajan ES, Izard T, Choe H (2020). The D614G mutation in the SARS-CoV-2 spike protein reduces S1 shedding and increases infectivity. bioRxiv https://doi.org/10.1101/2020.06.12.148726

\section{Tables}


Table 1

Information about the samples used in this study.

\begin{tabular}{|c|c|c|c|c|c|}
\hline City & SamplingDate & $\begin{array}{l}\text { Number of } \\
\text { samples }\end{array}$ & $\begin{array}{l}\text { Ages of } \\
\text { Animals }\end{array}$ & $\begin{array}{l}\text { Samples } \\
\text { Species }\end{array}$ & Clinical Signs \\
\hline \multirow[t]{8}{*}{ Ankara } & 2001 & 2 & & Faeces & Diarrhea \\
\hline & 2014 & 1 & $7 d$ & Faeces & Diarrhea \\
\hline & 2017 & 3 & $2-4 m$ & $\begin{array}{l}\text { Nasal } \\
\text { discharge }\end{array}$ & Nasal discharge, cough \\
\hline & 2018 & 9 & $15 d$ & $\begin{array}{l}\text { Nasal } \\
\text { discharge }\end{array}$ & Nasal discharge, cough \\
\hline & 2018 & 4 & $8 \mathrm{~m}$ & $\begin{array}{l}\text { Nasal } \\
\text { discharge }\end{array}$ & Nasal discharge, cough \\
\hline & 2019 & 5 & & $\begin{array}{l}\text { Nasal } \\
\text { discharge }\end{array}$ & Nasal discharge, dyspnea \\
\hline & 2018 & 4 & $8 \mathrm{~m}$ & $\begin{array}{l}\text { Nasal } \\
\text { discharge }\end{array}$ & Nasal discharge, cough \\
\hline & 2019 & 7 & $15 d$ & $\begin{array}{l}\text { Nasal } \\
\text { discharge }\end{array}$ & $\begin{array}{l}\text { Nasal discharge, cough, } \\
\text { depression }\end{array}$ \\
\hline \multirow[t]{3}{*}{ Aksaray } & 2005 & 3 & & Faeces & Diarrhea, dehydration \\
\hline & 2006 & 2 & $11-14 \mathrm{~d}$ & Faeces & Diarrhea \\
\hline & 2008 & 2 & $5-15 d$ & Faeces & Diarrhea \\
\hline \multirow[t]{2}{*}{ Eskisehir } & 2006 & 3 & $15-20 \mathrm{~d}$ & Faeces & Diarrhea \\
\hline & 2006 & 1 & $15 d$ & Nasaldischarge & Nasal discharge, cough \\
\hline Kars & 2006 & 3 & & Faeces & Diarrhea, dehydration \\
\hline Van & 2006 & 2 & & Faeces & Diarrhea \\
\hline Kirklareli & 2011 & 1 & $70 \mathrm{~d}$ & Faeces & Diarrhea, anorexia \\
\hline \multirow[t]{2}{*}{ Erzurum } & 2014 & 2 & $2 y$ & $\begin{array}{l}\text { Nasal } \\
\text { discharge }\end{array}$ & Nasal discharge, cough \\
\hline & 2017 & 3 & $1 \mathrm{~m}$ & Faeces & Diarrhea \\
\hline S. Urfa & 2014 & 3 & $8-10 d$ & Faeces & Diarrhea, dehydration \\
\hline Amasya & 2015 & 2 & $4 \mathrm{~d}$ & Faeces & Diarrhea \\
\hline Cankiri & 2016 & 1 & $5 d$ & Faeces & Diarrhea, dehydration \\
\hline \multirow[t]{4}{*}{ Izmir } & 2013 & 1 & $14 \mathrm{~d}$ & Faeces & Diarrhea, dehydration \\
\hline & 2015 & 2 & $15 d$ & Faeces & Diarrhea \\
\hline & 2017 & 4 & $4 y$ & $\begin{array}{l}\text { Nasal } \\
\text { discharge }\end{array}$ & Nasal discharge \\
\hline & 2018 & 1 & $15 \mathrm{~d}$ & Faeces & Diarrhea \\
\hline
\end{tabular}




\begin{tabular}{|c|c|c|c|c|c|}
\hline City & SamplingDate & $\begin{array}{l}\text { Number of } \\
\text { samples }\end{array}$ & $\begin{array}{l}\text { Ages of } \\
\text { Animals }\end{array}$ & $\begin{array}{l}\text { Samples } \\
\text { Species }\end{array}$ & Clinical Signs \\
\hline & 2018 & 3 & $5 \geq y$ & $\begin{array}{l}\text { Nasal } \\
\text { discharge }\end{array}$ & Nasal discharge \\
\hline & 2019 & 2 & $15 d$ & $\begin{array}{l}\text { Nasal } \\
\text { discharge }\end{array}$ & Nasal discharge, cough \\
\hline \multirow[t]{2}{*}{ Denizli } & 2017 & 5 & $7-30 d$ & $\begin{array}{l}\text { Nasal } \\
\text { discharge }\end{array}$ & $\begin{array}{l}\text { Nasal discharge, cough, } \\
\text { anorexia }\end{array}$ \\
\hline & 2017 & 9 & $7 d-15 m$ & Faeces & $\begin{array}{l}\text { Diarrhea, anorexia, } \\
\text { dehydration }\end{array}$ \\
\hline \multirow[t]{2}{*}{ Burdur } & 2019 & 5 & $1,5-9 \mathrm{~m}$ & $\begin{array}{l}\text { Nasal } \\
\text { discharge }\end{array}$ & Nasal discharge \\
\hline & 2019 & 5 & $1-1,5 y$ & $\begin{array}{l}\text { Nasal } \\
\text { discharge }\end{array}$ & Nasal discharge, cough \\
\hline Hatay & 2019 & 4 & & $\begin{array}{l}\text { Nasal } \\
\text { discharge }\end{array}$ & $\begin{array}{l}\text { Nasal discharge, cough, } \\
\text { dyspnea }\end{array}$ \\
\hline \multirow[t]{2}{*}{ Tokat } & 2018 & 5 & $15 \mathrm{~d}-8 \mathrm{~m}$ & $\begin{array}{l}\text { Nasal } \\
\text { discharge }\end{array}$ & Nasal discharge, cough \\
\hline & 2019 & 10 & $45-90 d$ & $\begin{array}{l}\text { Nasal } \\
\text { discharge }\end{array}$ & Nasal discharge, cough \\
\hline
\end{tabular}


Table 2

The accession numbers of the partial gene fragment and full-length sequences of the S gene of local BCoVs.

\begin{tabular}{|c|c|c|c|c|c|c|c|c|c|}
\hline \multirow[t]{2}{*}{$\mathrm{BCoV}$ isolate name } & \multicolumn{9}{|c|}{ Primer Pair } \\
\hline & SA & SB & SC & SD & SE & SF & SG & $\mathrm{SH}$ & S1 \\
\hline BCoV/Turkey/4950/2015 * & \multicolumn{8}{|c|}{ MK989620 } & + \\
\hline BCoV/Turkey/4945/2015 * & \multicolumn{8}{|c|}{ MK989621 } & + \\
\hline BCoV/Turkey/U1/2014 * & \multicolumn{8}{|c|}{ MK989622 } & + \\
\hline BCoV/Turkey/S8/2017 & \multicolumn{8}{|c|}{ MK989624 } & + \\
\hline BCoV/Turkey/T5/2018 & \multicolumn{8}{|c|}{ MK989623 } & + \\
\hline BCoV/Turkey/G76/2015 * & \multicolumn{4}{|c|}{ MK989628 } & - & \multicolumn{3}{|c|}{ MK989629 } & + \\
\hline BCoV/Turkey/G83/2015 * & \multicolumn{2}{|c|}{ MK989630 } & MK989631 & - & - & \multicolumn{3}{|c|}{ MK989632 } & + \\
\hline BCoV/Turkey/H1/2013 * & - & - & MK989633 & - & - & - & \multicolumn{2}{|c|}{ MK989634 } & + \\
\hline BCoV/Turkey/79/2018 & \multicolumn{3}{|c|}{ MK989627 } & - & - & - & - & - & + \\
\hline BCoV/Turkey/8553/2015 * & - & - & - & - & - & - & - & - & MK989626 \\
\hline BCoV/Turkey/1N/2019 & - & - & - & - & - & - & - & - & MK989625 \\
\hline \multicolumn{10}{|c|}{$\begin{array}{l}\text { S1 partially sequenced region ( } 488 \mathrm{bp} \text { ) was located in the region amplified with the SC and SD primers, thus, } \\
\text { additional accession number was not taken. } \\
\text { Faeces samples are marked with an asterisk }(*) \text {. }\end{array}$} \\
\hline
\end{tabular}


Table 3

Amino acid variations BCoVs S gene. Asterisk $\left(^{\star}\right)$ represent amino acids identical to the reference sequence. The strains investigated in this study are indicated by black.

\begin{tabular}{|c|c|c|c|c|c|c|c|c|c|c|c|c|}
\hline Strain / Isolate Name & 458 & 465 & 470 & 484 & 499 & 501 & 509 & 525 & 531 & 543 & 571 & 608 \\
\hline BCoV/USA/Mebus/1971 & $\mathrm{F}$ & V & $\mathrm{H}$ & $S$ & $\mathrm{~N}$ & $\mathrm{P}$ & $\mathrm{N}$ & $\mathrm{H}$ & $\mathrm{N}$ & $S$ & Y & $\mathrm{D}$ \\
\hline BCoV/Turkey/1N/2019 & * & * & * & * & * & * & * & * & * & * & * & - \\
\hline BCoV/Turkey/4950/2015 & * & $A$ & $\mathrm{D}$ & $\mathrm{T}$ & $S$ & $S$ & $\mathrm{~T}$ & $\mathrm{Y}$ & $\mathrm{D}$ & $A$ & $\mathrm{H}$ & G \\
\hline BCoV/Turkey/4945/2015 & * & $A$ & $\mathrm{D}$ & $\mathrm{T}$ & S & $S$ & $\mathrm{~T}$ & Y & D & $A$ & $\mathrm{H}$ & G \\
\hline BCoV/Turkey/U1/2014 & $S$ & $A$ & $\mathrm{D}$ & $\mathrm{T}$ & S & $S$ & $\mathrm{~T}$ & $\mathrm{Y}$ & $\mathrm{D}$ & $A$ & $\mathrm{H}$ & G \\
\hline BCoV/Turkey/G76/2015 & $S$ & $A$ & $\mathrm{D}$ & $\mathrm{T}$ & S & $S$ & $\mathrm{~T}$ & Y & $\mathrm{D}$ & $A$ & $\mathrm{H}$ & G \\
\hline BCoV/Turkey/G83/2015 & S & $A$ & $\mathrm{D}$ & $\mathrm{T}$ & S & $S$ & $\mathrm{~T}$ & Y & D & $A$ & $\mathrm{H}$ & - \\
\hline BCoV/Turkey/H1/2013 & * & $A$ & $\mathrm{D}$ & $\mathrm{T}$ & S & $S$ & * & Y & $\mathrm{D}$ & $A$ & $\mathrm{H}$ & - \\
\hline BCoV/Turkey/8553/2015 & $S$ & $A$ & $\mathrm{D}$ & $\mathrm{T}$ & $S$ & $S$ & $\mathrm{~T}$ & Y & $\mathrm{D}$ & $A$ & $\mathrm{H}$ & - \\
\hline BCoV/Turkey/T5/2018 & $\mathrm{S}$ & $A$ & $\mathrm{D}$ & $\mathrm{T}$ & S & $S$ & $\mathrm{~T}$ & Y & $\mathrm{D}$ & $A$ & $\mathrm{H}$ & G \\
\hline BCoV/Turkey/S8/2017 & * & $A$ & $\mathrm{D}$ & $\mathrm{T}$ & $S$ & $S$ & * & Y & $\mathrm{D}$ & $A$ & $\mathrm{H}$ & G \\
\hline BCoV/Turkey/79/2018 & * & $A$ & $\mathrm{D}$ & $\mathrm{T}$ & $S$ & $S$ & $\mathrm{~T}$ & Y & $\mathrm{D}$ & $A$ & $\mathrm{H}$ & - \\
\hline BCoV/Turkey/AN4/2005 & $\mathrm{S}$ & $A$ & * & $\mathrm{T}$ & * & $S$ & * & * & D & * & * & - \\
\hline BCoV/Turkey/AN11/2005 & $S$ & $A$ & * & $\mathrm{T}$ & S & $S$ & * & Y & D & G & $\mathrm{H}$ & - \\
\hline BCoV/USA/LY138/1965 & $S$ & * & $\mathrm{D}$ & $\mathrm{T}$ & $S$ & $S$ & * & * & * & * & * & * \\
\hline BCoV/China/HLJ-14/2015 & S & $A$ & $\mathrm{D}$ & $\mathrm{T}$ & * & $S$ & * & * & $\mathrm{D}$ & $A$ & * & * \\
\hline BCoV/Denmark/05 - 2/2005 & $S$ & $A$ & $\mathrm{D}$ & $\mathrm{T}$ & S & $\mathrm{F}$ & * & * & $\mathrm{D}$ & $A$ & $\mathrm{H}$ & G \\
\hline BCoV/France/-/1979 & $S$ & * & $\mathrm{D}$ & $\mathrm{T}$ & * & * & * & * & * & * & * & * \\
\hline BCoV/S.Korea/KCD10/2007 & $S$ & $A$ & $\mathrm{D}$ & $\mathrm{T}$ & S & $S$ & * & * & $\mathrm{D}$ & $A$ & * & * \\
\hline BCoV/Sweden/C-92/1992 & $S$ & $A$ & $\mathrm{D}$ & $\mathrm{T}$ & $\mathrm{T}$ & * & $\mathrm{T}$ & * & $\mathrm{D}$ & * & $\mathrm{H}$ & G \\
\hline BCoV/Italy/339-06/2006 & $S$ & $A$ & * & $\mathrm{T}$ & $\mathrm{T}$ & $S$ & * & Y & $\mathrm{D}$ & $A$ & $\mathrm{H}$ & G \\
\hline BCoV/Japan/Kakegawa/1976 & $\mathrm{S}$ & * & $\mathrm{D}$ & $\mathrm{T}$ & * & * & * & * & $\mathrm{D}$ & * & * & * \\
\hline BCoV/Vietnamese/PL84/2017 & $S$ & $A$ & $\mathrm{D}$ & $\mathrm{T}$ & S & $S$ & $\mathrm{H}$ & * & $\mathrm{D}$ & $A$ & $\mathrm{H}$ & * \\
\hline BCoV/USA/LSU/1994 & $S$ & $A$ & $\mathrm{D}$ & $\mathrm{T}$ & S & $S$ & * & * & G & $A$ & * & * \\
\hline BCoV/Germany/G95/1989 & S & $A$ & $\mathrm{D}$ & $\mathrm{T}$ & $\mathrm{T}$ & * & $\mathrm{T}$ & * & $\mathrm{D}$ & * & $\mathrm{H}$ & G \\
\hline BCoV/Denmark/05 - 3/2005 & $S$ & $A$ & $\mathrm{D}$ & $\mathrm{T}$ & S & $\mathrm{F}$ & * & * & $\mathrm{D}$ & $A$ & $\mathrm{H}$ & G \\
\hline BCoV/France/EPICaen01/2005 & $S$ & $A$ & $\mathrm{D}$ & $\mathrm{T}$ & $S$ & $S$ & * & Y & $\mathrm{D}$ & $A$ & $\mathrm{H}$ & G \\
\hline BCoV/S.Korea/KWD1/2005 & S & $A$ & $\mathrm{D}$ & $\mathrm{T}$ & S & S & * & * & D & $A$ & * & * \\
\hline BCoV/Sweden/U-09-3/2009 & $S$ & $A$ & $\mathrm{D}$ & $\mathrm{T}$ & S & S & * & Y & $\mathrm{D}$ & $A$ & $\mathrm{H}$ & G \\
\hline BCoV/Italy/438-06TN/2008 & $S$ & $A$ & $\mathrm{D}$ & $\mathrm{T}$ & S & S & * & $Y$ & $D$ & $A$ & $\mathrm{H}$ & $\mathrm{G}$ \\
\hline
\end{tabular}




\begin{tabular}{|lllllllllllll|}
\hline Strain / Isolate Name & 458 & 465 & 470 & 484 & 499 & 501 & 509 & 525 & 531 & 543 & 571 & 608 \\
\hline BCoV/Germany/V270/1983 & S & $*$ & $*$ & T & $*$ & $*$ & $*$ & $*$ & D & $*$ & $*$ & $*$ \\
\hline
\end{tabular}

\section{Figures}

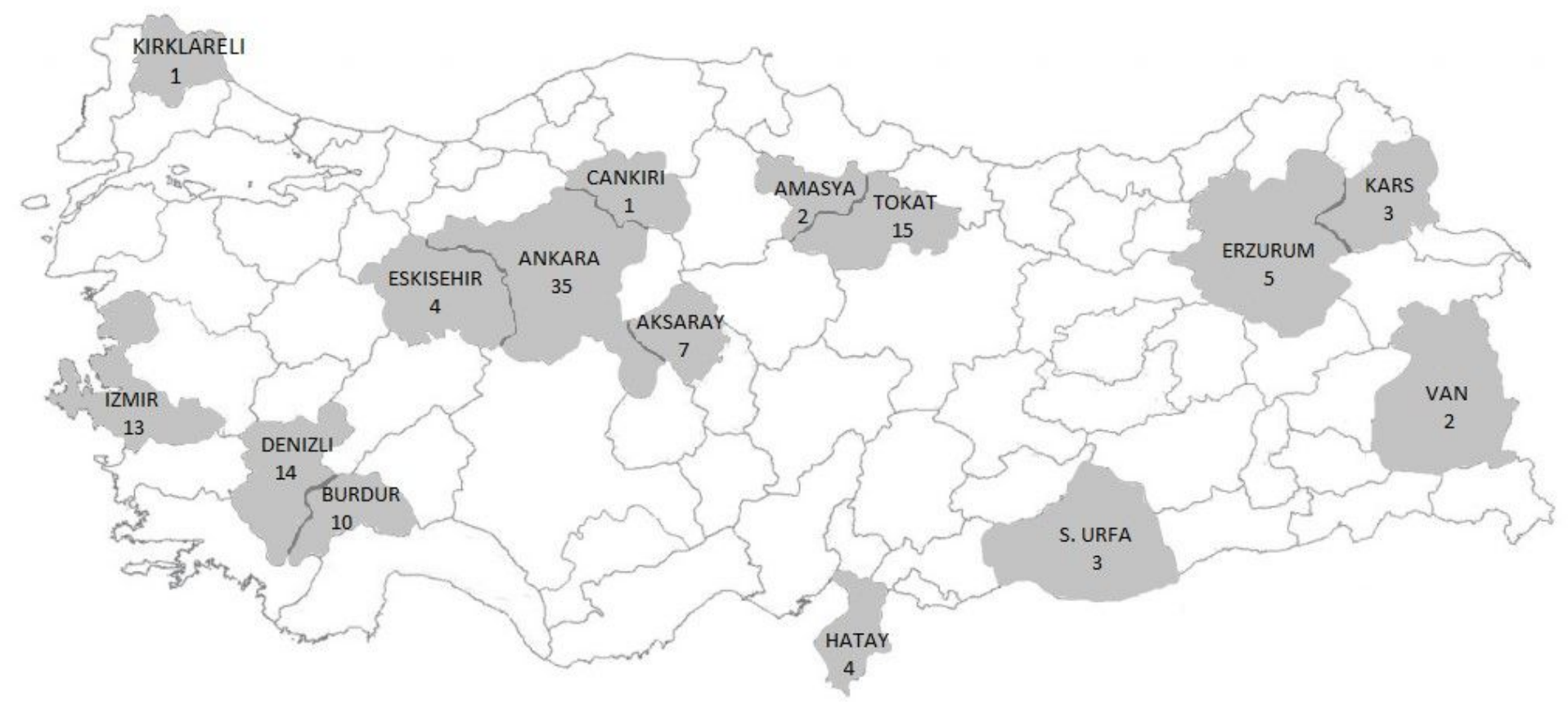

\section{Figure 1}

The map showing the cities where the farms are located in this study. Grey color indicates the cities where the farms are located, and numbers indicate the sample numbers provided. Note: The designations employed and the presentation of the material on this map do not imply the expression of any opinion whatsoever on the part of Research Square concerning the legal status of any country, territory, city or area or of its authorities, or concerning the delimitation of its frontiers or boundaries. This map has been provided by the authors. 
A

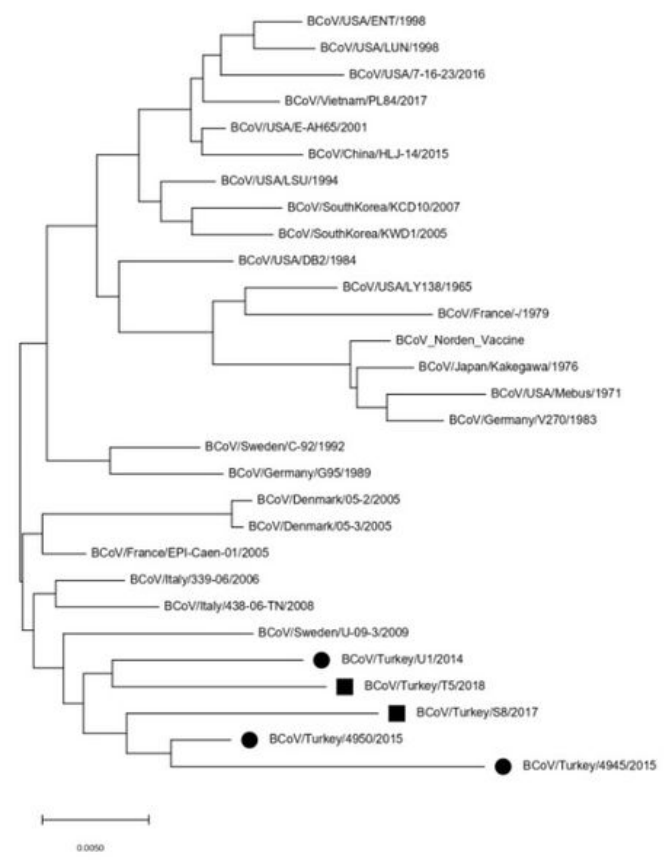

C

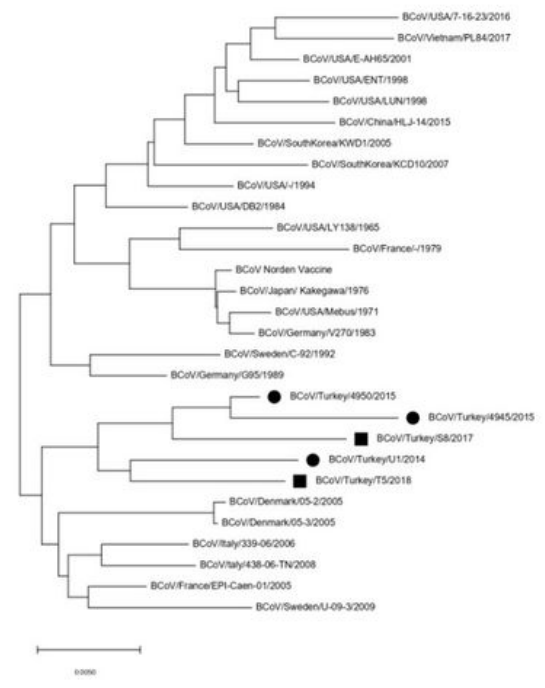

B

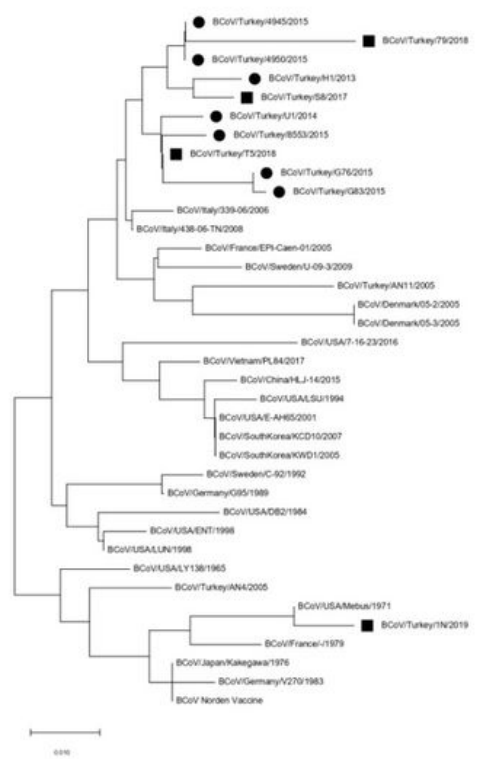

D

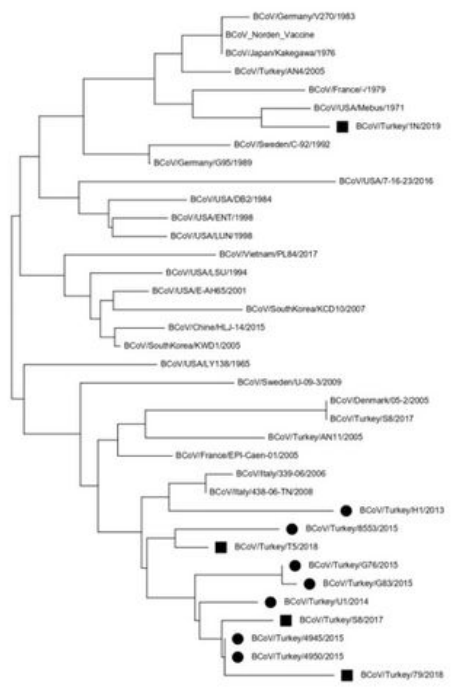

$-$

Figure 2

The phylogenetic tree constructed using the partial (B and $D$ ) or full-length ( $A$ and $C$ ) $S$ gene sequences of local BCoV from Turkey and reference BCoV strains from other countries. * Phylogenetic trees seen in A and B were prepared using amino acid sequences, those in $C$ and $D$ were prepared using nucleic acid sequences. The strains from faeces and nasal discharge samples in this study are indicated by black circle and square, respectively. The tree was constructed by the Neighbor-Joining method with bootstrap values calculated for 1000 replicates.

\section{Supplementary Files}

This is a list of supplementary files associated with this preprint. Click to download.

- Supplement.docx 